\title{
IMPLEMENTATION OF BLENDED LEARNING AS A MODEL OF INFORMATIONAL EDUCATIVE RESOURCE FOR LEARNING FOREIGN LANGUAGES
}

\section{Elena Shcherbakova ${ }^{1}$ \\ Svitlana Nikiforchuk ${ }^{2}$}

DOI: https://doi.org/10.30525/978-9934-588-38-9-23

\begin{abstract}
The purpose of the paper is to summarise and present different approaches to blended learning and to give the example of the way the students implement their text analysis in practice. The survey is based on the scientific works of prominent Ukrainian, Russian and European scholars. Today the traditional learning system is outdated on the background of life dynamics so among the modern approaches to learning the leading place takes a combined or blended learning. The analysis of publications and thesises on the issue of blended learning technologies usage allowed to define a number of distinctive features of blended learning that are represented in this paper. Having studied the concept of blended learning and its essence, the authors analysed the main advantages and disadvantages associated with using this form of learning in the learning process and defined the main forms of bleneded learning implementation. There is also an example of how the students can use encyclopedia Britannica to prepare an independent work on the functioning of various types of lexemes on the strong and weak positions of the texts of biographical encyclopedic articles.
\end{abstract}

\section{Introduction}

One of the most important criteria for a successful training system in the University is the flexibility and dynamics of its development. Updating innovative technologies today offer a wide range of opportunities for the introduction of new, instandard types and forms of education that will make

${ }^{1}$ Candidate of Pedagogical Sciences,

Assistant Lecturer at Department of English Language and Literature,

V.O. Sukhomlynsky National University, Ukraine

${ }^{2}$ Lecturer at Department of English Language and Literature,

V.O. Sukhomlynsky National University, Ukraine 
the process of learning a foreign language more productive and efficient and will meet the requirements of each individual student.

Today the traditional learning system is outdated on the background of life dynamics. It can not give the students necessary knowledge and skills. Designed for step by step stationary study of a Subject, not focused on the personalization of each individual student, the traditional form of education leads to the fact that both tutors and students face a lot of problems in the learning process. For example, the trite reduction of auditorial hours leads to deplorable consequences: it becomes almost impossible to teach the student the necessary skills in foreign language proficiency. In addition, the traditional learning system does not take into consideration the fact that each student has his own level of knowledge of the appropriate Subject and needs a personalized approach. These are just some of the issues complicating the process of learning a foreign language [5]. An effective solution to these and many other problems is the implementation of blended learning as well as the usage of informational and educational resources while studying the Subject matter.

The use of informational technologies in recent years has significantly changed education in the leading countries of the world. It is difficult to imagine the educational process without social services today. There have been developed new pedagogical approaches and open courses in which hundreds of thousands of listeners study for free. Innovative changes in modern Ukrainian education have been reflected in scientific works of V. Andruschenko, S. Goncharenko, M. Yevtukh, G. Yelnikova, O. Kovalenko, V. Lozovaya, P. Stefanyk, N. Tverezovskaya, O. Yaroshenko etc.

Among the modern approaches to learning the leading place takes a combined or blended learning, which was first mentioned by foreign scientists in 1995 [4]. The model of blended learnig is very logically correlated with the credit-modular system of the educational process, and its usage is advisable and desirable, since there is a possibility of optimal combination of auditorial, independent and individual work, practical training for students studying a foreign language. There are many different definitions of blended learning at the moment. Most scientists define blended learning as a «combination of distance and traditional communication in integrated training activity» [9]. In addition, this term is used to describe the learning which successfully combines various types of training activities, primarily paying attention to such types of learning as face-to-face, live e-mail train- 
ing and self-paced learning [10]. At the same time the scientist S. Graham admits that blended learning is aimed at the integration of traditional teaching and computer-indirect training in pedagogical environment [8].

Paying attention to different approaches in learning, there are three main components of the blended learning model, which are most common in the modern educational environment: full-time learning - a traditional format of auditorial classes in a teacher-student model; independent learning, which provides students with an independent research (network search, for example) and online (distance) learning, which gives an opportunity to organize the work of students and teachers online (for example, using Internet Conferences or Skype). All of these components should be well organized methodically and function in a constant connection with each other.

Blended learning promotes the optimization of resources and time, learning becomes more open, the students have an opportunity to learn to manage their studies and experience different types of motivation and are usually ready to successfully complete the course. One of the main advantages of using this method is its performance concerning maximal productivity of the teacher's and student's working time and also increase of the student's responsibility for his studies. In consequence of this method the student not only studies a specific Subject but also learns to learn.

The methodology of blended learning can also be attributed to the methods of learning foreign languages in some professional sphere, which are based on communicative approach. At the same time, the process of direct personal communication takes place online thanks to the computer language learning systems that help to create a virtual learning environment. Learning environment for learning a foreign language is created by a teacher and can have the following forms of teaching material presentation as lectures, colloquiums, individual or group online projects, virtual classroom that allows students to gain some share of freedom in the learning process.

The educational material designed as an online course material can be easily used and available to each student for self-mastering at a convenient time. The video conference discusses the most interesting and important course topics on colloquiums. It is supposed to use a variety of different tools - chat, forum, e-mail - which give students the opportunity to communicate, develop skills to work in the Internet and analyze information from different sources as well as skills to work together with the group, to distribute the duties and 
responsibilities for the performance of work properly. By means of such tasks a student can gain the skills necessary for his future professional activity.

\section{The distinctive features of blended learning}

The analysis of publications and thesises on the issue of blended learning technologies usage allows to define a number of distinctive features of blended learning:

1) the change in the rapport of tutors and students. The tutor in blended learning models performs several interrelated roles. The most important is the role of an assistant of the students in choosing an educational path and a consultant on research of educational material. The organizational role suggests that the tutor remains the key figure of the educational process, but his activity is connected with the implementation of several other functions: from uttering the educational materials and implementation of some «interface» between the field of scientific knowledge and the students he proceeds to the role of the educational process organizer. The role of the tutor as a lecturer fits in the traditional frames of ideas about pedagogical activity and implies the preparation of lecture material in electronic form, receiving questions of the students about the lectures as well as additional consultancy on complex questions with the help of e-mail or online [7];

2) organization of independent cognitive activity of students. The basis of the educational process at blended learning is purposeful, intensive and supervised independent work of the student (mastering the material, work in forums and chats, communication via e-mail and social networks). He can learn in a convenient place, on an individual agreed schedule, using a complex of special means of training and the possibility of contact with a tutor. In this way, the training focuses on the student who is supervised in learning. Blended learning stimulates the development of skills of self-education and information search (the necessity to study the material induvidually promotes the development of a responsible attitude to learning, self-motivation, planning of time, personal activity in the search of information);

3) organization of individual support of each student educational activities by the tutor, as on the basis of online communication usage through receiving the feedback from the tutor who implements an individual approach in practice, so with the help of knowledge acquisition «face to face», which educates and stimulates due to the influence of the tutor's personality; 
4) organization of group educational activities including joint work on projects, conducting discussions, seminars organized in the form of electronic teleconferences, forums, synchronous and asynchronous on time. It appears to be much more group work in terms of blended learning so it stimulates the development of online communication skills;

5) flexibility of the program, allowing the student to choose the necessary module, comfortable tempo, time and place for training, to control the volume and speed of mastering the material independently;

6) the possibility of balancing the level of basic knowledge by students at the expense of remote study of the material (pre-studied material in electronic form allows to create a single knowledge base and speak one language);

7) the usage of educational and methodical content, which gives an opportunity to revise the necessary material in an online mode at any time; to track the change of your rating in an electronic register; to pass the tests; to test your knowledge of the subject; to read additional sources that correspond to the topics, use audio or video lectures, different graphics and so on. At the same time, students still have the opportunity to study traditionally as they are accustomed;

8) developing the educational process taking into account the diversity of training organization forms (these can be face-to-face meetings, teleconference, consultations via email or Skype, chat conversations and blogs, internet testing, online competition and others).

\section{The main advantages and disadvantages of blended learning}

It also makes sense to observe several advantages that are important for a student in blended learning (based on Moodle system). First of all, this method develops the skills of independent learning and self-control; gives more interactivity; stimulates active learning. Material availability and flexibility of learning also characterizes blended learning.

As for the main obstacles in the application of blended learning model, it is possible to identify the following: ineffective time management, lack of self-discipline, technical problems, problems of cooperation, difficulties in using the platform of electronic training and poor quality of the teaching material. All this requires a thorough improvement.

The problem of developing and using blended learning model during the study of a foreign language is particularly topical in relation to the specifics of the subject itself, which as considered by I. Lerner relates to a group 
of disciplines, the main component of which is the types of activities. It is foreign language learning that allows to use many on-line elements such as tests, texts, audio and video files in foreign languages. This promotes a more effective study of a foreign language, improvement of language, speech and socio-cultural competencies and besides it forms the professional competence of future specialists, supplies them with necessary professional-meaningful qualities, reveals their creative potential and extends the outlook.

One of the most important criteria for a successful training system in the University is the flexibility and dynamics of its development. The updating of innovative technologies today offers a wide range of opportunities for the introduction of new, instandard types and forms of education that will make the process of learning a foreign language more productive and efficient, meet the requirements of each individual student.

Having studied the concept of blended learning and its essence, it is also important to analyse the main advantages and disadvantages associated with using this form of learning in the learning process. It should be mentioned that the benefits of blended learning can be divided into two groups: advantages related to the organization of the educational process and the benefits for its participants and subjects.

The first advantage is openness and flexibility of learning process. Under openness we mean the fact that blended learning makes it possible to attract much more participants during studies as opposed to traditional form of education. As for flexibility - every participant of educational process has permanent access to educational materials in electronic environment. That is, students and tutors can apply to any content they need at any time convenient for them.

The next advantage of blended learning is that in the process of this form of training a personalized approach is implemented. It means that each student has the ability to choose individually the necessary tempo, rhythm and volume of educational material. This allows him to build an individual learning path.

Another advantage is that the form of blended learning contributes to the development of educational autonomy of students. From the first day of studies the student learns to plan and effectively organize his academic activities, focusing on the final result. It is impossible not to mention that participation of students in webinars and conferences, group discussions and forums, increases their motivation in learning and interest in studying in general. 
Obviously, blended learning does not imply full autonomy to students. This form of learning gives the tutor an opportunity to monitor the educational process and make the necessary corrections. Students, in their turn, have the opportunity to see the results of their activities on time, to receive estimation of their work and the tutor's recommendations for improvement.

Learning a foreign language requires constant close contact of the tutor with students and students with each other. In such a close relationship each side has its own specific functions. Concerning the tutor, under a new form of learning, he ceases to be a «transmitter» of knowledge and becomes the coordinator who organizes the synergy of students and impells them to independent activity. The student, in his turn, from the passive consumer of ready knowledge becomes an active participant of the educational process. Thus, his motivation, independence and discipline increase.

\section{Lexical-semantic analysis of biographical article}

Today the use of electronic resources is very important, including the use of electronic encyclopedias, online dictionaries (to translate or interpret words), etc. The British encyclopedia Britannica can be singled out as rather popular in usage during studies. It was first published in the second half of the XVIII century but during the XIX-XX centuries it was supplemented and published many times, becoming a collection of scientific treatises of the most important sections of human knowledge. The modern electronic encyclopedia Britannica aims to provide the reader with a popular, complete and clear theme description thanks to publications of the most prominent authorities in science, politics and art. Of course electronic encyclopaedias are mostly used for independent work of the students, especially in the study of lexical-semantic or stylistic text analysis. Let's take a look at how the students can use encyclopedia Britannica to prepare an independent work on the functioning of various types of lexemes on the strong and weak positions of the texts of biographical encyclopedic articles. For this type of text analysis, the students are suggested to select several biographical articles from the electronic encyclopedia Britannica at their own discretion and, using the example below, analyse selected texts and draw conclusions about the features of encyclopedic biographical articles of the British linguistic tradition. 


\section{Example of biographical articles analysis.}

\section{Initial position}

The initial position is the first paragraph of the biographical encyclopedic article since its integral feature is the anthropocentric character.

The invariant features of the initial position of the texts.

1. Specifying lexemes. The name of the personality is expressed by such lexemes as "original name», «in full» or «nee», which specify the true or full name of the person: «Meryl Streep, original name Mary Louise Streep», "Barbara C. Jordan, in full Barbara Charline Jordan», "Katie Couric, in full Katherine Anne Couric», "Harriet Beecher Stowe, nee Harriet Elizabeth Beecher», "Margaret Hilda Thatcher, Baroness Thatcher of Kesteven, nee Margaret Hilda Roberts», "Jacqueline Kennedy Onassis, née Jacqueline Lee Bouvier, later (1953 - 68) Jacqueline Kennedy ", "Angela Merkel, née Angela Dorothea Kasner» [11].

2. Lexemes that nominate a profession or occupation of the personality: «queen of England», «lyric poet», «actress», «ethologist», "educator», "politician》, «national security adviser», «singer», «composer», «director», "producer», «writer», «cohost», «anchor», «lawyer», "painter», "philosopher of modern nursing, statistician, and social reformer», «physicist», «first lady» [11].

3. Temporal pointers. Lexical temporal pointers identify the time continuity: «Feb. 21, 1936 - Jan. 17, 1996», «January 7, 1957», «June 14, 1811 - July 1, 1896», «for 50 Years», «in the 1960's and 70's», «in 1971», «1973-79», «19th century», «1558 - 1603», «July 28, 1929-May 19, 1994» [11]. Considering the grammatical way of expressing the category of time, we can admit that the initial position of the texts of the British linguistic tradition is characterized by the dominance of the Past Simple Tense. The most frequent are the verbs «born», «died», «was», «lived», «became» [11].

4. Toponyms and toponymy adjectives form a spatial continuity of the text: "Connecticut», "Birmingham, Alabama», "Grantham, Lincolnshire», "Amherst, Massachusetts», "London, England», "Arlington, Virginia», «Newport News, Virginia», «Texas», «U.S.», «German-American», «American», «Polish-born», «India», «Pakistan», «Italian», «British» [11].

\section{Axiologeme (attitudinal lexemes).}

The initial position of the text is characterized by frequent functioning of axiologemes that promotes the formation of the first impression of the recipient about the outstanding personality, for example: «outstanding», «a major 
sex symbol», «the sole winner», «famous», «slender, stylish», «radiant beauty», "charming innocence», "whose [Marlene Dietrich] beauty, voice, aura of sophistication, and languid sensuality made her one of the world's most glamorous film stars», "who [Jacqueline Kennedy Onassis] was noted for her style and elegance», "one of the foremost celebrities of her day», «most celebrated». "Bette Davis, original name Ruth Elizabeth Davis (born April 5, 1908, Lowell, Massachusetts, U.S. - died October 6, 1989, Neuilly-sur-Seine, France), versatile, volatile American actress, whose raw, unbridled intensity kept her at the top of her profession for 50 years». From the very first sentence of a biographical article the recipient imagines a multifaceted, changeable personality, which, along with this, demonstrates the dramatic nature and unbridled strength of spirit. But, despite the presence of axiologemes with the negative assessment, such qualities of a person as an unbridled force of spirit and a sharp nature belong to the advantages rather than the shortcomings of the person of this profession since these traits contributed to the brilliant career for 50 years. In another example: «She is considered by many to be the greatest popular singer of her generation» [11] the use of the adjective great in the superlative degree of comparison indicates the uniqueness of the individual, her high achievements in the professional sphere.

Variative signs of the initial position of the texts.

1. Lexemes indicating historical time. Sometimes an initial position is marked by lexemes, which directly or indirectly represent historical time and help the recipient to perceive the realities of the text in the texts of biographical articles: "American Civil War», "President George Bush», "Crimean War», "Elizabethan Age» [11].

2. Gender-marked lexemes (GML). Grammatical GMLs are represented by such pronouns as: personal - she, posessive - her, reflexive - herself. We are able to highlight such discriptive oriented GML as "physicist», "philosopher», "politician», «ballerina», «actress», «writer», "painter», «novelist», "playwright», "founder», "poet», «cohost», «ethologist» [11]. Pragmatically oriented gender-marked lexemes have an emotionally-assessed coloring: "The first major female star to command roles as Jewish actress, Straisand redefined female stardom in the 1960's and 70's with her sensitive portrayal of ethnic urban characters» [11]. It should be noted that in the analyzed articles such gender-marked lexemes as female star and female stardom are mainly expressed by word-groups in which one lexeme 
has an emotionally-attitudinal coloration and the other denotes the social or professional status of a person, for example: «Margaret Hilda Roberts, Europe's first woman prime minister, "She was the first African American congresswoman to come from South», "Katie Couric, American broadcast journalist, best known as the longtime cohost of the NBCA'S Today show and as the first solo female anchor of a major network (CBS) evening news program», "the first female chancellor of Germany», "She [Marie Curie] was the first woman to win a Nobel Prize, and she is the only woman to win the award in two different fields», "She [Florence Nightingale] was the first woman awarded the Order of Merit», "who [ Benazir Bhutto] became the first woman leader of a Muslim nation in modern history» [11]. These lexemes relate to pragmatically orientated gender-marked lexemes and almost all of them have a positive emotional-attitudinal coloration since they emphasize the professional achievements of prominent women. Also such lexemes as Jewish actress and African American congresswoman deserve special attention since they denote the racial background of the personality. On the one hand, this may indicate an implicit manifestation of racism in relation to the individual, and on the other hand, it emphasizes the achievement of high social status despite the racial background.

3. Lexemes indicating the family relationship: "Artemisia Gentileschi, daughter of Orazio Gentileschi», "Jacqueline Kennedy Onassis, the wife of John F. Kennedy, 35th president of the United States», "Diana, Princess of Wales, former consort (1981 - 96) of Charles, Prince of Wales; Mother of the heir second in line to the British throne, Prince William, Duke of Cambridge» [11]. The use of such lexemes underlines the fact that these women became known due to outstanding parents or successful marriages.

4. Lexemes nominating nicknames of the personalities: "Elizabeth $I$, byname The Virgin Queen, or Good Queen Bess», «Florence Nightingale, byname Lady with The Lamp», "Jacqueline Kennedy Onassis, née Jacqueline Lee Bouvier, later (1953 - 68) Jacqueline Kennedy, ByName Jackie» [11]. The nicknames represent the personalities, point to their special features and distinguish them from other personalities. The nickname «Good Queen Bess» shows that the people of England loved and respected the Queen, considered her to be balanced, fair and serious leader of the state who loved and respected the citizens. The Queen was called "The Virgin Queen» because she decided never to marry and always claimed that all her 
relationships with men had a purely platonic character. Florence Nightingale received the nickname «Lady with the Lamp» for the fact that during the Crimean War, nursing the wounded, every night she took the lamp and went through all the wards herself. This nickname outlines such features of her character as attentiveness, self-sacrifice, kindness and devotion to her work. The Americans named Jacqueline Kennedy «Jackie» because she was the youngest first lady in the White House in history, so the president and his wife were called simply «John and Jackie» which emphasizes the affection of the American people to this couple.

Medial position

The invariant features of the medial position of the texts.

1. Axiologemes both with positive and negative attitude are used in encyclopedic biographical articles of the British linguistic tradition. It is necessary to underline that axiologemes with negative attitude have a low frequency but fully implement a pragmatic function. For example: «unsuccessful», "fierce», "uncompromising», "an awkward ugly duckling», "a weak stage voice», "manic-depressive Psychosis», "mental and physical instability», «meticulous», "unhappy», "severe chronic pain», "suffered», "lived on bread and butter and tea», "was assassinated», "considerable disappointment and sadness», "vulnerable», "deceptive», "she [Elizabeth I] was skilled at manipulating factions» [11]. Despite the negative coloration these axiologemes emphasize that prominent personalities, even having defects in character, appearance or life troubles, were able to successfully realize themselves in society.

Axiologemes with positive attitude are implemented in the text with the help of different parts of speech:

a) adjectives «excellent», «best-selling», «skilled», «remarkable», "folksy», "the highest-paid», "affective», «zealous», «important and influential», "majestic», "cautious and impassive», "stylish», "charming», «ideal», «admirable», «successful», «talented», «most-photographed», «powerful», «prodigious», «unforgettable» [11];

b) nouns «blend of shrewdness», "courage», "symbol of the Naton's destiny», «self-control», «acumen», «infatuation», «blend of charm and imperiousness», "graciousness», «challenge», «beauty», «innocence», "stardom», "goddess», «sex-symbol», «affinity», «fashion sense», «dignity», "popularity», «maturity», «achievement», «contribution», «creation», «musicality» [11]; 
c) verbs «overcome», «compromise», «retain power», «taking matters into her own hands», "to enchant», "founded», «was honoured», «was beatified», «was awarded», «excelled», «to serve», «improved», "gained the respect» [11];

d) adverbs «brilliantly», «reverently», «skillfully», «highly» [11].

2. Toponyms and toponymy adjectives: «New York», «Manhattan», «Hollywood», "Africa», "Gombe Stream Game Reserve», "Washington», «New Zealand», «Denver», «Stanford», «British and Swiss», «London», «Dubai», «Germany», «Crimean Peninsula», «Paris», «Indian», «Holland» [11].

3. Temporal pointers: «In 1952», «during the 1960», «until 1972», «in the 1950s», "in the early 1980S», "during the U.S. invasion of Panama», "at that time», "for 18 years», «in February 1975», "over the next 10 years» [11].

4. Lexemes representing the names of educational institutions: "University of Virginia», "High School», "Texas Suothern University», "Harvard University», "Boston University Law School», "Tuskegee University», "University of Oxford», "School in Hartford», "Cushing Academy», "The University of Cambridge», "George Washington University», "the Institute of The Blessed Virgin Mary», "Visva-Bharati University» [11].

5. Lexemes denoting the names of establishments where the personality worked (or works): «The Cable News Network», «CNN Atlanta base», "Chick Webb Orchestra», «Texas House of Representatives», «Texas Senate», «Broadway», «Universal Pictures», «Washington Times-Herald», «The White House», «Max Reinhardt Deutsche Theaterschule», «Paramount Pictures», «Florence Academy of Design» [11].

6. Anthroponyms (friends, acquaintances, employers, partners of personalities): "Debora Norville», "Connee Boswell», «Benny Goodman», "Louis Armstrong», «Norman Granz», «Lyndon Johnson», «Murray Kinnel», «Louis Leakey», "Leonardo DiCaprio», "Letitia Baldridge», «Joe DiMaggio», «Josef von Sternberg», "Popo John XXIII», «Mary, Queen of Scots», «Pope Pius V», «Francis Bacon», "Queen Victoria», «Prince Albert» [11].

7. Proper names that denote the products of professional activity of the personality (books, films, songs, scientific works): «Love and Kisses», "The Mayflower», "Uncle Tom's Cabin; Or, Life Among the Lowly», "Kramer vs. Kramer», "Death Becomes Her», "The Bridges of Madison County», "Of Human Bondage», "The Barbra Streisand Album», "the Jane Goodall Institute», "Hamlet», "Gentlemen Prefer Blonds», "The Misfits», "The Devil is a Woman», "Murder on the Orient Express», «Roman Holiday» [11]. 
8. Lexemes that represent the position of the person: "desk assistant》, "assignment editor», "political correspondent», "weekend anchor», "legislator», "research chemist», «minister», "author», "actress», "paleontologist», «reporter-photographer», «nurse», «model», «dancer», «minister of information and broadcasting», «teacher», "professor» [11].

Variative features of the medial position of the texts.

1. Lexemes indicating historical time: "World war II», "during the Third Reich», "the Medici Court», «Elizabethan Age», "Renaissance», «World war I», "Crimean War», "Iraq war» [11].

2. Proper names which denote the highest awards received by the personality: «Nobel Prize for Peace», «Padma Shri [one of the highest civilian honours]», "Bharat Ratna [the highest civilian honour]», "an Academy Award», "a Tony Award», "Nobel Prize for Physics», "Nobel Prize for Chemistry», "the Order of Merit» [11].

3. Quotations: «Her [Elizabeth I] mind has no womanly weakness, «Ascham wrote with the unselfconscious sexism of the age, "her perseverance is equal to that of a man, and her memory long keeps what it quickly picks up»; "If ever any person, "wrote one enthusiastic observer, "had either the gift or the style to win the hearts of people, it was this Queen [Elizabeth I], and if ever she did express the same it was at that present, in coupling mildness with majesty as she did, and in stately stooping to the meanest sort»; "God hath revealed to some in this our age that it is more than a monster in nature that a woman should reign and bear empire above man»; "She [Elizabeth I] is a Princess, "the French ambassador remarked, «who can act any part she pleases»; «left no doubtings whose daughter she was»; "We all loved her [Elizabeth I], "Harington wrote with just a trace of irony, "for she said she loved us»; "She [Elizabeth I] imagined, "wrote Francis Bacon a few years after the queen's death, "that the people, who are much influenced by externals, would be diverted by the glitter of her jewels, from noticing the decay of her personal attractions»; Her [Marilyn Monroe] death was ruled a «probable suicide»; President Kennedy jokingly reintroduced himself to reporters as the «the man who accompanied Jacqueline Kennedy to Paris.» [11].

4. Self-quotations. Elizabeth I: "Away with those torches! we can see well enough»; "I am but one body, naturally considered, "Elizabeth declared in her accession speech, "though by [God's] permission a Body Politic to govern»; "I will have here but one mistress and no master»; "I do assure 
you, there is no prince that loveth his subjects better, or whose love can countervail our love. There is no jewel, be it of never so rich a price, which I set before this jewel; I mean, your love: for I do more esteem of it, than of any treasure or riches»; "I know I have the body of a weak and feeble woman, "Elizabeth declared, "but I have the heart and stomach of a king, and of a king of England too». "Hitler is an idiot, "she [Marlene Dietrich] stated in one wartime interview. Nightingale said it was the «Kingdom of Hell.» [11].

The presence of quotations and self-quotations in biographical articles is motivated by the author's desire to provide more reliable information about the personalities relying on the statement of her contemporaries or the sayings of their own.

5. Gender-marked lexemes: «two lovers», «female skills», «the first woman and the first non-Catholic to lead the party", "not only the first woman to hold the office but also the first East German", "she was the first woman to teach in the Sorbonne», "woman's fate in a society that has no use for woman's stronger, more "masculine» talents», "received the rigorous education normally reserved for male heirs», "...she joined Florence's Academy of Design, the first woman to do so»; "world-weary female lead», "a femme fatale» [11].

6. Variative features of the biographical articles of the British linguistic tradition also include the description of a family relationship or a state of personalities: "Winslet was raised in a family of actors», "Sam Mendes, whom she had married in 2003 (they divorsed in 2010)», "she married a Dutch photographer...(later they divorced)», «married four times», "Harriet Beecher was a member of one of the $19^{\text {th }}$ century's most remarkable families. The daughter of the prominent Congregationalist minister...she grew up in an atmosphere of learning and moral earnestness», "she married Calvin Ellis Stowe, a clergyman and seminary professor, an eminent biblical scholar», "her brother Henry Ward Beecher was editor», "The daughter of Alfred Roberts, a grocer and local alderman (and later mayor of Grantham), and Beatrice Ethel Stephenson», "she married a wealthy industrialist, Denis Thatcher», "Jordan was the youngest of three daughters in a close-knit family», "the daughter of a writer and a journalist» [11].

Final position

The final position of the text is the last paragraph of a biographical article. The main task of the final position of the text of the article is to summa- 
rize all the achievements of the outstanding personality. It is reflected in the frequent usage of the lexemes that denote the titles of awards or received titles: "Golden Globe Award», "Oscar», "Commander in the Order of Arts and Letters», "member of the American Academy of Arts and Letters», "Kennedy Center Honor", "an award from the Recording Academy for lifetime achievement», "a medal from the French Legion of Honour», "Grammy Awards», «Emmy Award», "Commander of the Order of the British Empire», "a member of the Order of the Garter», "U.S. Presidential Medal of Freedom», "Dame of the Order of the British Empire» [11] and proper names of published works (autobiografies, scientific works, fiction): "The Minister's Wooing», "The Soviet Union and the Czechoslovak Army, 19481983: Uncertain Allegiance», "Germany Unified and Europe Transformed: A Study in Statecraft», "In the Shadow of Man», "The Chimpanzees of Gombe: Patterns of Behaviour», "The Best Advice I Ever Got: Lessons from Extraordinary Lives», "Barbara Jordan, a Self-Portrait», "The Lonely Life», "This'n'That» [11]. It is obvious that in parallel with these lexemes the temporal lexemes indicating the year of receiving an award, title or writing of the book are actualized.

The final position is characterized by less frequency of axiologemes in comparison with the initial position: «alone», «cost her much of her popularity», "a leading author», "a political force», "recipient of numerous honours", "her clear tone and wide vocal range», "her mastery of rhythm, harmony, intonation, and diction», "an excellent ballad singer, conveying a winsome, ingenuous quality», «influential», "one of the most sought-after actresses», "admired», "dumb and sensitive blond», "cultural icon», "personal magnetism, androgynous image and glamour», «image of female authority, regal magnificence, and national pride» [11].

Self-quotations have low frequency on the final position of the texts: Mother Teresa: Mother Teresa: "My God, my God, why have you forsaken me?» [11] and quotations: In the words of the critic Kenneth Tynan: "She has sex, but no particular gender. She has the bearing of a man; the characters she plays love power and wear trousers. Her masculinity appeals to women and her sexuality to men.»; Ernest Hemingway, said, "If she had nothing more than her voice, she could break your heart with it» [11].

It should also be noted the appearance of gender-marked lexemes on the final position of the texts: "In 1995 Marie Curie's ashes were enshrined 
in the Panthéon in Paris; she was the first woman to receive this honour for her own achievements», "the first woman to receive the Order of Merit», «In 1995 Marie Curie's ashes were enshrined in the Panthéon in Paris; she was the first woman to receive this honour for her own achievements» [11].

The final position of the texts of biographical articles of British linguistic tradition is characterized by the implementation of the lexemes which denote the names of awards, titles and names of printed works of personalities. We also distinguish the low frequency of axiologemes, quotations, self-quotations and gender-marked lexemes in the final positions of the texts.

Thus, using an online encyclopedia, the given example of the lexical-semantic analysis of encyclopedic biographical articles as well as the possibility to consult with the tutor about the implementation of this type of independent work, the students not only study a particular discipline but can plan their time to perform this type of work and express their own opinions and observations of the peculiarities of the British linguistic tradition.

\section{Conclusions}

Considering the above advantages of blended learning, we can make a conclusion about the necessity of using this form of studies in educational institutions. However, as any other innovations, the introduction of blended learning into the educational process is complicated by a large group of factors that exist in the system of higher professional training. The need of universities in electronic educational content can be related to objective factors. Its creation is impossible without material outfit and technical equipment as well as the availability of skilled specialists. Many higher educational institutions have a great need to improve the skills of the teaching staff in the field of e-learning. Such indicators can complicate the integration of blended learning into the educational process as the factor of introducing such a form is a high level of computer qualification not only for students but also for tutors. Unfortunately, statistics notes very low motivation of tutors, especially with years of experience, to mastering new methods of working with students [2].

Nowadays blended learning, as one of the varieties of e-learning, is increasingly included in the practice of the modern university. Most often it is implemented as the use of informative and educational resources in fulltime studies with some elements of asynchronous and synchronous distance 
learning, which allows to simultaneously use the benefits of the full-time learning and the advantages of distance technologies, first of all collectively-distributed forms of activities organization [3].

The implementation of blended learning involves preserving the general principles of the traditional educational process building with the use of e-learning elements (electronic informative and educational resources, informative and telecommunicative technologies). Thus the process of combining the technologies can occur both on the level of a separate course, discipline and on the level of the educational programme as a whole. E.V. Andropova and E.V. Kondakova regard mixed learning as the technology which unites such method of training as face to face and all sorts of methods and resources of distance education [1]. According to Y.I. Kapustin, blended learning should be understood as a purposeful, organized, interactive process of cooperation between the tutor and the student with each other and with the means of learning, moreover the process of learning is invariant as to their location in space and time [3].

In terms of implementing blended learning it is typical for the educational process of the university to use various forms reflecting the nature of education. In this context the form of education refers to the structure of educational process associated with the time and place of studies; number of students; the order of interaction between the learners and the tutor; dedactic means. There are such forms of blended learning as: auditorial training that involves direct contact between the students and the tutor; the case of education which is focused on independent work of the students and provided with a set of didactic means made on different material media; learning in networks which is organized through the tool environment and includes communication in forums, chats, etc.

Consequently, blended learning combines the efficiency of distance learning and the vividness of face-to-face meetings, which allows to make it interesting and useful for students. Numerous publications which study this type of education are recognized as one of the main directions of improving the quality of students' training and effectiveness of the European system of continuous education. This form of education provides undeniable advantages both for tutors and students. It is necessary to emphasize that blended learning allows to optimize the tutor's working time as well as to improve the efficiency of the training process in general. The student becomes an 
active participant of the educational process capable of building his individual training path based on his own needs. This contributes to the formation of competent specialist, competitive in the modern environment.

\section{References:}

1. Andropova E.V. (2009). Tekhnologiya smeshannogo obucheniya i ee rol' v povyshenii kachestva obrazovaniya [The technology of blended learning and its role in the improvement of education quality]. Informatika i obrazovanie, vol. 8, pp. 112-114.

2. Baryshnikov N.V., Sokolova I.Yu. (2014). Smeshannoe obuchenie kak forma organizatsii uchebnogo protsessa po inostrannomu yazyku v vuze [Bleneded learning as a form of educational process organization in the universities studying foreign languages]. Tomsk. (in Russian)

3. Kapustin, Yu.I. (2007). Pedagogicheskie i organizatsionnye usloviya effektivnogo sochetaniya ochnogo obucheniya i primeneniya tekhnologiy distantsionnogo obucheniya [Pedagogical and organizational conditions of effective combination between full-time learning and the implementation of distance learning]. Moscow. (in Russian)

4. Kostina E.V. (2010). Model' smeshannogo obucheniya (Blended Learning) i ee ispol'zovanie v prepodavanii inostrannykh yazykov [The model of blended learning and its implementation in learning foreign languages]. Izvestiya vysshikh uchebnykh zavedeniy. Seriya: Gumanitarnye nauki, vol. 1, no. 2, pp. 141-144.

5. Mel'chenkova N.V. (2015). Ispol'zovanie smeshannogo obucheniya inostrannomu yazyku $\mathrm{v}$ vuze dlya povysheniya effektivnosti uchebnogo protsessa [The use of blended learning of foreign languages for the improvement of educational process effectiveness]. Pedagogika, pp. 1063-1065.

6. Polat E.S., Bukharkina M.Yu., Moiseeva M.V. (2004). Teoriya i praktika distantsionnogo obucheniya [Theory and practice of distant learning]. Moscow: Akademiya. (in Russian)

7. Fodeman, Doug/ Safe practices for life online: a guide for middle and high school / Doug Fodeman and Marje Monroe / International society for Technology in Education. - Eugene, Oregon, Washington, DC, 2008, 241 p.

8. Graham, C.R. (2005). Blended learning system: Definition, current trends and future direction. In: Bonk, C.J., Graham, C.R. (eds.) Handbook of Blended Learning: Global Perspectives, Local Designs, pp. 3-21. Pfeiffer, San Francisco.

9. Moebs, S. \& Weibelzahl, S. (2006). Towards a good mix in blended learning for small and medium sized enterprises - Outline of a Delphi Study. Proceedings of the Workshop on Blended Learning and SMEs held in conjuction with the 1st European Conference on Technology Enhancing Learning Crete, Greece, pp. 1-6.

10. Purnima V. Blended Learning Models // Published: August 2002. P. 1. URL: http://www.learningcircuits.org/2002/aug2002/valiathan.html

11. Britannica Online Encyclopedia. URL: http://www.britannica.com 